\title{
Students' Understanding of the Use of Foreign Terms Contained in The Sports Columnof Rakyat Bengkulu Online Newspaper
}

\author{
Genni \\ Institut Agama Islam Negeri Bengkulu \\ genniegennie26@gmail.com \\ Bustomi \\ Bustomi.hasan@iainbengkulu.ac.id \\ Institut Agama Islam Negeri Bengkulu \\ Randi \\ Institut Agama Islam Negeri Bengkulu \\ Randijufry@gmail.com
}

\begin{abstract}
This study aims to determine the ability of Indonesian Language Study Program students at IAIN Bengkulu in understanding foreign terms contained in the sports column of the Rakyat bengkulu online newspaper. Data research methods in quantitative methods are used to describe the data. The results of the research on the use of foreign terms are equally developed due to the influence of globalization and the interaction between one language and another. The difference between loanwords and foreign terms is that loanwords are adapted to Indonesian language rules so that they undergo spelling adjustments according to good and correct Indonesian spelling guidelines, while foreign terms come from books in foreign languages whose use is international and customary by experts in their fields and entered into Indonesian based on: (a) more subtle connotations; (b) short words from the translation; and (c) are international rather than equivalent. It is concluded that the data on the ability to understand foreign terms as language variations in the Rakyat bengkulu online sports column. Based on the calculation, the average value of students' ability to understand foreign terms in the sports column of the Rakyat bengkulu online newspaper is 13.37. Then the percentage obtained is $66.85 \%$. When consulted with a scale of five is quite sufficient. From the discussion above, it can be seen that the average ability of students to understand foreign terms as language variations in the sports column of the Rakyat bengkulu online newspaper is quite adequate with an average value of 13.37. The researcher suggests Indonesian students to understand foreign terms as language variations in the sports column of the Rakyat bengkulu online newspaper. Which has been made with the implementation of learning so that learning takes place in a structured manner.
\end{abstract}

Keywords: student; foreign terms; Bengkulu people

\section{A. Introduction}


Language is the regular expression of human thoughts and feelings that use sound as a tool. In everyday communication, one of the tools that is most often used is language, both spoken and written language. We are so close to languages, especially Indonesian, that we do not feel the need to explore and study Indonesian further. As a result, as language users, Indonesians are not skilled at using language. An unconscious weakness (Kridalaksana, 1993).

Language as a tool for communication is a use of journalistic language contained in newspapers. Journalistic language itself has an understanding as a diversity which is usually used in newspapers and then will be read by all levels of diverse societies. In language, it is used in mass media, both audio, visual and print mass media. Usually the mass media that is more popular in the community is the mass media in the form of print. This is due to the diversity of print mass media, for example newspapers in print.

Newspapers aim to provide information that is usually always awaited by all members of the community. Usually in newspapers, it is not only needed by certain circles. However, newspapers are also needed by all members of the community with the aim of adding information that will be useful for all members of the community. In addition, newspapers not only provide real information to all readers, usually newspapers can also be used for readers to express an opinion, as well as ideas that people want to have.

Language can be said as a series of sounds that can produce real human speech tools. Language can also be said as a system in the form of sound symbols that have articulation meaning (which results in human speech tools) usually always arbitrary and conventional, which are usually always used by humans in communicating which will produce feelings and thoughts. Complete and effective communication can be used in conveying ideas, messages, intentions, feelings and opinions that can be expressed with others.

In this case, we recognize that there are variations in language, which is a nonformal language that is currently developing, this language is very dominantly used 
and favored by people, especially sports fans today. This language is a language that is becoming a variation of the language used in society. The diversity of language itself has its own characteristics, the only thing that distinguishes it is from the speech language of sports with the speech of other languages. These characteristics can be seen in the choice of vocabulary, expressions, patterns, and structures.

This variation of language is used by the writers of magazines, sports tabloids, and newspapers to liven up the atmosphere or atmosphere of sports in conveying information. In other words, it is hoped that it can be used as a useful tool, namely to treat socially about a variety of language which is now widely used by enthusiasts in the field of sports. In this case, the language variation in the sports column in the Rakyat bengkulu Daily tends to be more dominant than the other columns in the Rakyat bengkulu Newspaper. Newspaper mass media always provide information that people will usually wait for every day. Usually not only certain people who need newspapers but the whole community will need newspapers.

The data obtained in this newspaper is also very diverse and interesting, there are many variations of languages that are currently popular. For example, the word Off roader, which is found in the following sentences: The competition is to establish a relationship between fellow off roaders and fight for 1st, 2nd and 3rd place winners. This event is a form of competition for the 4th RAC Anniversary to build friendship and intimacy ahead of the closing of 2014. The meaning of the off roader vocabulary was originally in the form of English vocabulary which means to control a vehicle that is driven outside the highway, whether it is a road that is still dirt, mud, sand, river, or rocks, then changed to an off roader, so that they said that driving an off-road car becomes an off-roader, which means an off-road car driver.

Along with the times, the use of foreign terms is always changing. Lots of new vocabulary popping up. Everyone, especially sports lovers, currently uses language variations so that they are no longer limited to one particular social group. There is a tendency to develop language variations from year to year. The author wants to describe foreign terms used by the Rakyat bengkulu newspaper in the sports column 
in the Rakyat bengkulu daily in terms of usage and meaning. Researchers consider this research important because the presence of foreign terms in society can increase vocabulary and knowledge in language. With this research, it is expected to be able to understand the variation of language according to the meaning contained in the sentence.

Based on the background and problems above, the author feels the need to conduct a study of this language variation with the title "Students' Understanding of the Use of Foreign Terms in the Sports Column of the Rakyat Bengkulu Online Newspaper (A Study of Indonesian Tadris Study Program Students, State Islamic Institute of Bengkulu)".

\section{B. Research Method}

This research used a Descriptive method. Descriptive method can be defined as a problem-solving procedure that will be investigated by drawing or describing the state of the research subject/object (a person, institution, community, etc.) (Sugiyono, 2008).

At the present time based on the facts that appear or as they are. Quantitative descriptive method was used to describe the data on " Students' Understanding of the Use of Foreign Terms in the Sports Column of the Rakyat Bengkulu Online Newspaper". The type of research used to collect data in this study was quantitative descriptive method. This method is used to get a picture of a situation that is taking place now, that quantitative descriptive method is research that aims to explain existing phenomena by using numbers.

\section{Result and Discussion}

1. Results The ability of students of the Indonesian Language Study Program at IAIN Bengkulu in understanding the use of foreign terms contained in the Sports Column of the Rakyat Bengkulu Online Newspaper 
This chapter discusses the results of the research and discusses the data that has been researched found when conducting research. The ability of students of the Indonesian Language Study Program at IAIN Bengkulu in understanding the use of foreign terms contained in the Sports Column of the Rakyat Bengkulu Online Newspaper is as follows:

Table 1.

Data on students' ability to understand foreign terms as language variations in the sports column of the Rakyat Bengkulu newspaper

\begin{tabular}{|c|c|c|c|c|}
\hline No & Name & Scores & Pecentage & Description \\
\hline 1. & Nurul Fitri & 17 & 85 & Very good \\
\hline 2. & Mahdiyah Fatina sanyah & 16 & 80 & Good \\
\hline 3. & Sopi Ensela & 14 & 70 & Enough \\
\hline 4. & Janita Aisah Purnama & 16 & 80 & Good \\
\hline 5. & Ainur Rohmah & 17 & 85 & Very good \\
\hline 6. & Sitti Fathiah Fajriani & 15 & 75 & Good \\
\hline 7. & Rahmad Zaki Apriansyah & 13 & 65 & Enough \\
\hline 8. & Nafikri Nafiakun A. & 16 & 80 & Good \\
\hline 9. & Ana Sari & 14 & 70 & Enough \\
\hline 10. & Henita & 14 & 70 & Enough \\
\hline 11. & Monica Hidayah & 13 & 65 & Enough \\
\hline 12. & Zingki Inggrawansyah & 17 & 85 & Very good \\
\hline 13. & Edo Sugandi & 13 & 65 & Enough \\
\hline 14. & Deya Rahma & 16 & 80 & Good \\
\hline 15. & Intan Pratami & 14 & 70 & Enough \\
\hline 16. & Puji Pera Monica & 12 & 60 & Enough \\
\hline 17. & Rahmad Hidayat & 14 & 70 & Enough \\
\hline 18. & Deka Mardatillah & 14 & 70 & Enough \\
\hline 19. & Fera Rindiani & 11 & 55 & Not enough \\
\hline 20. & Sely Ariska & 7 & 35 & Fail \\
\hline 21. & Reifika koumala Sari & 9 & 45 & Not enough \\
\hline 22. & Meta Deslia Putri & 4 & 20 & Fail \\
\hline 23. & Heni Aprilia & 16 & 80 & Good \\
\hline 24. & $\begin{array}{l}\text { Olivia Wedika Putri } \\
\text { Tarigan }\end{array}$ & 15 & 75 & Good \\
\hline 25. & Nilla Nurhaliza & 15 & 75 & Good \\
\hline 26. & Selvia Deva Kurnia & 17 & 85 & Very good \\
\hline 27. & Veni Puspita Sari & 16 & 80 & Good \\
\hline
\end{tabular}




\begin{tabular}{|c|c|c|c|c|}
\hline 28. & Dina Permata Sari & 13 & 65 & Enough \\
\hline 29. & Indah Puspitas Sari & 11 & 55 & Not enough \\
\hline 30. & Ema Oktavyanti & 12 & 60 & Enough \\
\hline 31. & Ririn Puspita Anggraini & 17 & 85 & Very good \\
\hline 32. & Gino Ariya Pradana & 18 & 90 & Very good \\
\hline 33. & Piona Monika & 11 & 55 & Not enough \\
\hline 34. & Chintia Ayu Wulandari & 12 & 60 & Enough \\
\hline 35. & Siti Kasana & 18 & 90 & Very good \\
\hline 36. & Oktiansa Hamdani & 13 & 65 & Enough \\
\hline 37. & Mita Silvia & 14 & 70 & Enough \\
\hline 38. & Muhammad Alfa Radzi & 20 & 100 & Very good \\
\hline 39. & Popon Hayati & 14 & 70 & Enough \\
\hline 40. & Yowan Melda Yolan & 13 & 65 & Enough \\
\hline 41. & Venti Ayu Lestari & 11 & 55 & Not enough \\
\hline 42. & Annysha Kurnia Syafitri & 11 & 55 & Not enough \\
\hline 43. & Ericha Rianda Marzoli & 13 & 65 & Enough \\
\hline 44. & Cucu Eka Rahmawati & 12 & 60 & Enough \\
\hline 45. & Risna Arista & 13 & 65 & Enough \\
\hline 46. & Tika Okta Sari & 13 & 65 & Enough \\
\hline 47. & Dwi Ayu Lestari & 10 & 50 & Not enough \\
\hline 48. & Prindi Pransisko & 19 & 95 & Very good \\
\hline 49. & Arpan Susanto & 15 & 75 & Good \\
\hline 50. & Lia Novitasari & 13 & 65 & Enough \\
\hline 51. & Widia Lestari & 15 & 75 & Good \\
\hline 52. & Deka Gusti Sulastri & 18 & 90 & Very good \\
\hline 53. & Dela larasati & 18 & 90 & Very good \\
\hline 54. & Ayu Wulandari & 9 & 45 & Not enough \\
\hline 55. & Erliana & 11 & 55 & Not enough \\
\hline 56. & Pebriansyah & 13 & 65 & Enough \\
\hline 57. & Dina Apriyanti & 16 & 80 & Good \\
\hline 58. & Era Pitriana & 9 & 45 & Not enough \\
\hline 59. & Lia Rusanti & 14 & 70 & Enough \\
\hline 60. & Putjah Aisyah Padhillah & 16 & 80 & Good \\
\hline 61. & Rinda Ahtisyah & 15 & 75 & Good \\
\hline 62. & Nina Suryani & 10 & 50 & Not enough \\
\hline 63. & Diko Saputra & 10 & 50 & Not enough \\
\hline 64. & Dito Saputera & 19 & 95 & Very good \\
\hline 65. & Msy Tiara Novita & 6 & 30 & Fail \\
\hline 66. & Novriza Yulianti & 12 & 60 & Enough \\
\hline 67. & Popy Hosni & 3 & 15 & Fail \\
\hline 68. & Rike Dwiyanti & 9 & 45 & Not enough \\
\hline
\end{tabular}




\begin{tabular}{|c|l|l|c|l|}
\hline 69. & Farezi Zomba & 18 & 90 & Very good \\
\hline 70. & Yuni Pertiwi & 8 & 40 & Not enough \\
\hline 71. & Dyah Agusti Angriani & 13 & 65 & Enough \\
\hline 72. & Ongki Gusfika & 20 & 100 & Very good \\
\hline 73. & Mita Hikma Rani & 15 & 75 & Good \\
\hline 74. & Lisa Afriani & 12 & 60 & Enough \\
\hline 75. & Nira Meliza Sartika & 13 & 65 & Enough \\
\hline 76. & Yogi Apri Yanto & 13 & 65 & Enough \\
\hline 77. & Rice Mairani Anggraini & 4 & 20 & Fail \\
\hline & Total & 1.030 & 5.150 & \\
\hline
\end{tabular}

\section{Annotation}

Scores : Student scores on the answers to the questionnaire

$\% \quad$ : Scores percentage

The average value is a percentage, then the following results are obtained:

$$
\begin{aligned}
M & =\frac{1.030}{77} \\
& =13,37
\end{aligned}
$$

The average value is presented, then the following values are obtained:

$$
\begin{aligned}
& S=\frac{13,37}{20} \times 100 \% \\
& =66,85 \%
\end{aligned}
$$

Based on the calculation, the average value of students' ability to understand foreign terms in the sports column of the Rakyat bengkulu online newspaper is 13.37. Then the percentage obtained is $66.85 \%$. when consulted with a scale of five, it is classified as good. From the discussion above, it can be seen that the average ability of students to understand foreign terms as a language variation in the sports column of the Rakyat bengkulu newspaper is classified as sufficient with an average value of 13.37. The ability of IAIN Bengkulu students to understand foreign terms in the sports column of the Rakyat bengkulu daily newspaper online is considered sufficient. 


\section{a. Analysis of Students' Ability to Use Foreign Terms in Sports Discourse}

\section{1) Student Ignorance of Foreign Terms in Sports Discourse in Rakyat bengkulu Daily Newspaper Online}

The findings when the researcher conducted the research showed that the insufficient understanding of foreign terms in the Sports Discourse in the Rakyat bengkulu Daily Newspaper was the result of not enough reading interest, especially those related to sports news, this of course would have an impact on the students' not enough ability in understand the meaning of these foreign terms.

Based on the results of the study and the findings at the time the researcher conducted the study, it showed several reasons for students' ignorance of the use of foreign terms that were often used in sports news including the infrequent reading of good news from print media and online media, especially related to sports news which contained foreign term users still felt lay and rarely heard or read.

In news writing, there are guidelines that serve as the basis for news writing. So that it is easy to understand and can attract audiences. One of them is the use of words must be efficient. By removing unnecessary words, short sentences can be made. But in the practice of journalism, long paragraphs and words are often found redundant in news writing. Wasteful words can be found in news headlines, leads and news content. This is often done by journalists who have been in the world of journalism for a long time.

Print mass media are mass media that convey information through writing. Language is a means of conveying information. It is clear whether or not the information conveyed to the public is determined whether or not the language used is correct. The use of good and correct language will determine the arrival of the information to the audience clearly. On the other hand, a language that is confused in conveying information will make it difficult for the audience to understand the information. In a journalistic perspective, every information presented must be true, 
clear and accurate. The language of the press or journalistic language is the language used in the mass media.

\section{2) Students who are not interested and have no hobbies with the world of sports so far Foreign terms in sports discourse in the Rakyat bengkulu Daily Newspaper are not understood.}

The findings in the field show that students have low interest in reading sports discourse in the Rakyat bengkulu Daily newspaper due to not enough interest so that the habit of reading sports news is low, this of course has an impact on students' ability to understand the use of foreign terms in a news.

The results also show that students are less interested in reading online media, especially those related to sports news, this is of course a result of low interest in reading so that the ability to master the use of foreign terms made in the news is reduced. These findings are one of the factors that cause the lack of ability to master the use of foreign terms, how low interest in reading among the younger generation in this millennium era is, as evidenced by the many syndromes of playing games both offline and online. The rapid development of the world of technology with all its features "pampers" young people to open social media instead of reading books. As a result, the fate of the books in the library is like a pile of dust as a nest of ghosts. Journalistic language is the language style used by journalists in writing news. It is also called the language of mass communication (language of mass communication, also called newspaper language), which is the language used in communication through mass media, good oral communication (speech) in electronic media (radio and TV) and written communication (print media), with the characteristics of short, concise and easy to understand.

\section{3) Women's Misunderstanding of Foreign Terms in Sports Discourse in Rakyat bengkulu Daily Newspaper Online}

Female students who lack interest in sports will certainly have an impact on interest and understanding of foreign terms but in fact women compared to men will 
have little interest which has an impact on Women's Misunderstanding of Foreign Terms in Sports Discourse in Daily Newspapers Bengkulu People Online.

"Women do not understand the world of sports, especially in the use of foreign terms. The use of language as a means of communication can be found in written and oral media. In written media such as newspapers which are used as a tool to convey information that is packaged in written form, while in oral media it can be found in electronic media such as television which presents information in the form of entertainment and news that is packaged either directly or indirectly. In this function, language is used to carry information from speakers to recipients or listeners so that recipients can receive information. Newspapers are one of the most important media for the community because newspapers are a communication tool used to convey news or information needed by the community. Even today, newspapers have reached people who live in rural areas and they can easily choose the variety of information they want according to their needs."

"With newspapers, people can receive information or news quickly. In addition, newspapers also function as a tool to support and encourage a major change in people's lives. Reading newspapers will increase one's insight about the development of life in the surrounding environment so that they know the actual situation and have a sense of responsibility to pay attention to the situation to make it even better. Information about things or events that have happened can be found in the stories written by journalists in newspapers. News is not the same as events. Events are meet. If the language used contains a lot of errors or confusion, it will result in less good, namely the reader's misunderstanding in understanding the information conveyed. Language as a means of communication is widely used in various fields of human life, for example: education, religion, economics, politics, art, and others. The language used in each of these fields has its own characteristics. These differences can be seen from the style of language, the use of terms, and the form of discourse. In general, the language of the newspaper should be short, concise but clear, and not circular. Thus, the Indonesian language used in delivering news or information in 
newspapers must be clear, concise, and simple so that readers can easily understand the information contained in newspapers.

\section{Discussion}

Data on the ability to understand foreign terms as language variations in the sports column of the Rakyat bengkulu newspaper. Based on the calculation, the average value of students' ability to understand foreign terms in the sports column of the Rakyat bengkulu newspaper is 13.37 . Then the percentage obtained is $66.85 \%$. when consulted with a scale of five, it is classified as good. From the discussion above, it can be seen that the average ability of students to understand foreign terms as a language variation in the sports column of the Rakyat bengkulu newspaper is classified as sufficient with an average value of 13.37 .

Language in a tangible form can be said to be a tool for communication that is used in the media of good newspapers used in writing that can be used by the whole community in expressing a good critique of the desires that exist in society (Tarigan, 1986). Different people make variations of the language that can be used to communicate. Community communication can be formed in newspapers so as to produce a variety of language that can be seen in terms of usage and in terms of formality (Kridalaksana, 1993).

The form of public communication in newspapers will produce language variations in terms of usage and in terms of formality (Chaer dan Agustina, 2010).

The application of language as a communication tool is the use of journalistic language in newspapers. Journalistic language is one of the varieties used in newspapers that are read by a very heterogeneous society. This language is used in all mass media, both audio, visual and print media (Sugiyono, 2015). that the mass media that has a high frequency of appearance and is widespread in society is the print media. This is due to the variety of print mass media that are spread in the community, such as newspapers, magazines and tabloids (Hairson, 2010).

The application of language as a communication tool is the use of journalistic language in newspapers. Journalistic language is one of the varieties used in 
newspapers that are read by a very heterogeneous society. This language is used in all mass media, both audio, visual and print media (Sugiyono, 2015). that the mass media that has a high frequency of appearance and is widespread in society is the print media. This is due to the variety of print mass media that are spread in the community, such as newspapers, magazines and tabloids.

\section{Conclusion}

Based on the results of the research that has been described in the discussion, a conclusion can be drawn, namely ability. Then it can be concluded that the ability data on understanding foreign terms as language variations in the sports column of the Bengkulu folk newspaper can be concluded. Based on the calculation, the average value of the ability of IAIN Bengkulu students to understand foreign terms in the sports column of the Rakyat bengkulu newspaper is 13.37. Then the percentage obtained is $66.85 \%$ classified as enough. When consulted with a scale of five, it is classified as good. From the above discussion, it can be seen that the average ability of students to understand foreign terms for sports, the Rakyat bengkulu Newspaper, is classified as sufficient with an average value of 13.37. The use of foreign terms is equally developed due to the influence of globalization and the interaction between one language and another.

\section{References}

Abidin, Y. (2014). Desain Sistem Pembelajaran Dalam Konteks Kurikulum 2013. Bandung: Refika Aditama.

Arikunto, S. (2006). Prosedur Penelitian Suatu Pendekatan Praktek. Jakarta: Rineka Cipta.

Daryanto. (2010). Media Pembelajaran. Yogyakarta: Gava Media.

Kridalaksana, H. (1993). Kamus Linguistik. Jakarta: Gramedia.

Kamus Besar Bahasa Indonesia. Jakarta: PT Gramedia Pustaka Utama.

Sugiono. (2008). Metode Penelitian Kuantitatif Kualitatif \& RND. Bandung: Alfabeta 
Hairson. (2010). Pengembangan Kurikulum Baru. Bandung: PT Remaja Rosdakarya Bandung.

Tarigan, H.G. (1986). Menyimak Sebagai Suatu Keterampilan Berbahasa. Bandung: Angkasa Bandung.

Sri, H. (2015). Pengaruh media audiovisual terhadap kemampuan menulis teks negosiasi oleh Mahasiswi kelas X SMA negeri 1 dolok masuk tahun pembelajaran 2014/2015.

Nic. P. (2009). Negosiasi Juara. Jakarta: Esensi.

Rohani,A. (2007). Psikologi Sosial. Jakarta: Rineka cipta.

Kosasih. (2013). Optimalisasi Media Pembelajaran. Jakarta: Gramedia.

Getteng, Rahman. (2012). Menuju Guru Profesional Dan Beretika. Makasar: Alauddin Press.

Yuli, H. (2016). Peningkatan Keterlaluan Menulis Teks Negosiasi Menggunakan Metode Inkuiri Mahasiswa Smti pontianak.

Zabadi, Fairul, \& dkk. (2013). Buku Guru Bahasa Indonesia Wahana Pengetahuan SP/MTs Kelas VII. Jakarta: Kemendikbud. 